\title{
Impact of Aluminum Toxicity on Physiological Aspects of Barley (Hordeum vulgare L.) Cultivars and its Alleviation through Ascorbic Acid and Salicylic Acid Seed Priming
}

\author{
M.D. Shahnawaz, Rajani Chouhan and Dheera Sanadhya*
}

School of Life and Basic Sciences, Jaipur National University, Jaipur, Rajasthan, India

*Corresponding author

\begin{tabular}{|c|c|}
\hline & A B S T R A C T \\
\hline & \multirow{7}{*}{$\begin{array}{l}\text { The effect of Aluminum toxicity on seed germination and other biochemical parameters of } \\
\text { two varieties of Barley (RD2052 and RD2552) differing in their sensitivity to aluminum } \\
\text { toxicity were studied. In present study different concentrations of Al (Control, } 2 \mathrm{mM}, 4 \mathrm{mM} \\
\text { and } 6 \mathrm{mM} \text { ) were used to impose Aluminum toxicity under in vitro condition and } \\
\text { amelioratingrole of Salicylic acid and Ascorbic acid by seed priming method was studied. } \\
\text { The complete experimental set was classified into three categories viz. (i) unprimed } \\
\text { seedlings with Aluminum treatment; (ii) Ascorbic acid Primed seedlings with Aluminum } \\
\text { treatment and (iii) Salicylic acid primed seedlings with Aluminum treatment. The seeds } \\
\text { were germinated under in vitro condition for six days. After six days of germination, } \\
\text { seedling parameters (Root length, Shoot length, Plant height, Fresh matter, Dry matter), } \\
\text { Photosynthetic pigments (Chl a, Chl b, Total Chl, Carotenoids), biochemical parameters } \\
\text { (Total sugar, Reducing sugar, Total soluble protein), enzymes of carbohydrate metabolism } \\
\text { (Invertase, Sucrose synthase and } \alpha \text {-amylase) and enzymes of Protein metabolism (Nitrate } \\
\text { Reductase and Protease)were analyzed. RD2052 was more affected under Al stress due to } \\
\text { its susceptible nature, while RD2552 showed better result and performed tolerant nature } \\
\text { against Al toxicity. All data were analyzed by the one way analysis of variation } \\
\text { (ANOVA). }\end{array}$} \\
\hline & \\
\hline HordeumVulgare & \\
\hline $\begin{array}{l}\text { L., Germination, } \\
\text { Al toxicity, } \\
\text { Ascorbic acid, } \\
\text { Salicylic acid. }\end{array}$ & \\
\hline Article Info & \\
\hline $\begin{array}{l}\text { Accepted: } \\
\text { 04 April } 2017 \\
\text { Available Online: } \\
\text { 10 May } 2017\end{array}$ & \\
\hline & \\
\hline
\end{tabular}

\section{Introduction}

$\mathrm{Al}$ toxicity is the primary factor limiting crop production in acid soils all over the world (Kochian, 1995). Soluble forms of $\mathrm{Al}\left[\mathrm{Al}^{3+}\right.$ or $\left.\mathrm{Al}\left(\mathrm{H}_{2} \mathrm{O}\right)_{6}{ }^{3+}\right]$ inhibit roots and shoot as well most of the plants leading to reduced growth and production. Toxic effects of $\mathrm{Al}$ lead to several physiological and biochemical changes in plants (Alvarez et al., 2012). Aluminum also confers negative effects on photosynthetic pigments; Cai et al., (2011) observed that Aluminum affects the quantity of chlorophyll pigments and suppression of photosynthetic activities at the photosynthetic apparatus. Wan (2007) suggested that the reduction in total sugars in Al stressed is related with arrested growth rate and reduction in photosynthetic pigments. Al also reduces the enzymatic activity of carbohydrate metabolism. Sucrose synthase and Invertase are important enzymes that convert sucrose into hexose (Sun et al., 1992). Al can cause harmful effects in the assimilation of nitrogen in the plants (Pal'oveBalang and Mistrik, 2011). Toxic effect of Al 
causes a reduction in nitrate concentration (Souza et al., 2014). Al alters protein and amino acid content due to changes in enzymes of protein metabolism (Azmat et al., 2015). Nitrate reductase and Protease are important enzymes for protein metabolism. This study was designed to investigate the protective role of Ascorbic acid (AA) and Salicylic acid (SA) in two barley varieties under Al stress by studying the seedling parameters, photosynthetic pigments, biochemical parameters, enzymes of carbohydrate metabolism and enzymes of protein metabolism.

\section{Materials and Methods}

\section{Study area and Plant material}

The present work was carried out in School of life Sciences, SIILAS Campus, Jaipur National University, Jaipur, Rajasthan, Barley (Hordeum vulgare L.) varieties (RD2052 and RD2552) were collected from Rajasthan Agriculture Research Institute Durgapura, Jaipur, Rajasthan.

Procedure of seed germination and priming with Ascorbic acid and Salicylic acid

Seeds were surface sterilized using0.1\% $\mathrm{HgCl}_{2}$ for 5 minutes and washed with distilled water repeatedly for three times. This study was targeted to analyze the effects of two plant growth regulators (AA and SA) seed priming in presence of Al toxicity. Seeds were primed according to the method given by Ansari and Sharif-Zadeh (2012). Seeds were soaked in salicylic acid $(250 \mu \mathrm{M})$ and ascorbic acid (2mM) solutions at $25{ }^{\circ} \mathrm{C}$ for 12 $\mathrm{h}$. The imbibed seeds were dried on filter paper at $25 \pm 2^{\circ} \mathrm{C}$ for $24 \mathrm{~h}$ and then germinated in glass petri dishes with different concentrations of aluminum $(\mathrm{C}, 2 \mathrm{mM}, 4 \mathrm{mM}$ and $6 \mathrm{mM}$ ) in $1 / 4$ strength Hoagland solutions at $\mathrm{pH} 4$. Seeds were allowed to germinate at $25 \pm 2{ }^{\circ} \mathrm{C}$ for six days in growth chamber. After six days the average seedling parameters (Root length, Shoot length, Plant height, Fresh matter and dry matter) were recorded.

\section{Estimation of Chlorophyll pigments}

Chlorophyll pigment was estimated according to the method given by Coombs et al., (1985). $0.2 \mathrm{~g}$ fresh leaves were homogenized in $14 \mathrm{ml}$ of $80 \%$ acetone followed by centrifugation at $10,000 \mathrm{rpm}$ for $10 \mathrm{~min}$. The absorbance of the supernatant was recorded at $647 \mathrm{~nm}, 664 \mathrm{~nm}$ and $470 \mathrm{~nm}$ against $80 \%$ acetone as blank for determination of Chlorophyll a (Chl a), Chlorophyll b (Chl b) Total Chlorophyll and Carotenoid).

Anthocyanin was estimated according to the method given by Swain and Hillis (1959).

$0.1 \mathrm{~g}$ fresh leaves were homogenate with $5 \mathrm{ml}$ $80 \%$ ethanol and centrifuged at $10000 \mathrm{rpm}$ for 10 min.1 $\mathrm{ml}$ of the alcohol extract was transferred into a test tube. $3 \mathrm{ml}$ of aqueous methanolic $\mathrm{HCl}(0.5 \mathrm{~N} \mathrm{HCl}$ in $85 \%$ methanol) and $1 \mathrm{ml}$ of anthocyanin reagent $(1 \mathrm{ml}$ of $30 \%$ $\mathrm{H}_{2} \mathrm{O}_{2}$ mixed with $9 \mathrm{ml}$ of methanolic $\mathrm{HCl}$ ) were added. The blank tube was prepared in the same manner by adding $1 \mathrm{ml}$ of aqueous methanolic $\mathrm{HCl}$ solution instead of anthocyanin reagent. All the tubes were kept in the dark for $15 \mathrm{~min}$ and measured the absorbance at $525 \mathrm{~nm}$ against the blank.

\section{Estimation of Carbohydrate and Free amino acid}

Extract preparation- The dried leaves $(0.05 \mathrm{~g})$ were homogenized in $10 \mathrm{ml}$ hot ethanol $(80 \%)$ and centrifuged at $2000 \mathrm{rpm}$ for 10 min. and supernatant was pooled and three $\mathrm{ml}$ of ethanol $(80 \%)$ was add to residue and recentrifuged and supernatant was pooled again in the same vessel and evaporate to 
dryness in china-dish on boiling water bath. The residue was eluted with $5 \mathrm{ml}$ of $20 \%$ ethanol and subject to analysis for total sugars, reducing sugars and free amino acids.

Total sugar was estimated according to the method given by Yemn and Willis (1954).

$4 \mathrm{ml}$ of chilled anthrone reagent (Anthrone reagent $0.2 \%$ was dissolved in $95 \%$ chilled Sulphuric acid), $50 \mu 1$ of ethanol extract and $950 \mu 1$ of $20 \%$ ethanol was added. These was then covered with glass marbles and immediately placed in boiling water bath for $10 \mathrm{~min}$. and cooled in ice bath. The absorbance of blue green color solution was read at $625 \mathrm{~nm}$ in spectrophotometer against blank containing $20 \%$ ethanol.

Reducing sugar was estimated by the method given by Sumner (1935).

$1 \mathrm{ml}$ of DNSA (dinitro-salicylic acid) reagent (1 $\mathrm{g}$ of DNSA was dissolved in $50 \mathrm{ml}$ distilled water, $1.6 \mathrm{~g}$ sodium hydroxide was added and dissolved $30 \mathrm{~g}$ of sodium potassium tartarate was added and thereafter the final volume was made up to $100 \mathrm{ml}$ with distilled water), ethanol extracts $(250 \mu 1)$ and $20 \%$ ethanol $(750 \mu 1)$ was added. The tubes of reaction mixture were kept at $100^{\circ} \mathrm{C}$ for 12 minutes in boiling water bath. $2 \mathrm{ml}$ of distilled water was subsequently added and absorbance was recorded at $560 \mathrm{~nm}$ against blank containing $20 \%$ ethanol in place of ethanol extract.

Amino acid estimation estimated by the method was given by Lee and Takahashi (1966).

$3.8 \mathrm{ml}$ Ninhydrin reagent (ninhydrin, 0.5 M citrate buffer and pure giycerol) was added to $1 \mathrm{ml}$ of ethanol extract and the content was shacked vigorously. The mixture was heated in boiling water bath for $12 \mathrm{~min}$ and cooled to room temperature in running tap water. The absorbance of the color solution was read at $570 \mathrm{~nm}$ against a blank containing $20 \%$ ethanol.

Total soluble protein estimation estimated by the method given by Bradford (1976).

Fresh leaves $0.1 \mathrm{~g}$ was homogenized in $1.5 \mathrm{ml}$ of $0.1 \mathrm{M}$ phosphate buffer (pH7.5) and transferred to eppendorf tubes. The homogenate was centrifuged at $8000 \mathrm{rpm}$ for $10 \mathrm{~min} .0 .1 \mathrm{ml}$ of supernatant was taken in tube and diluted by $1 \mathrm{ml}$ by $0.1 \mathrm{M}$ phosphate buffer ( $\mathrm{pH} 7.5$ ). Then $5 \mathrm{ml}$ of Bradford reagent (0.01 mg of Coomassie Brilliant Blue G-250 was dissolved in $50 \mathrm{ml}$ of ethanol and to this $100 \mathrm{ml}$ of $85 \%$ phosphoric acid) was added and mix thoroughly. Absorbance was recorded at 595nm against the blank.

\section{Determination of enzymes of Carbohydrates Metabolism}

Invertase activity was estimated according to the method given by Hawker and Hatch (1965).0.1gfresh plant material was homogenized in $1.5 \mathrm{mlof}$ chilled sodium acetate buffer (0.2 M pH4.8) containing polyvinyl pyrrolidone and centrifuged at $10,000 \mathrm{rpm}$ at $4^{\circ} \mathrm{C}$ for 10 minutes and supernatant was used as enzyme extract.

Reaction mixture was prepared by adding 0.6 $\mathrm{ml}$ of $(0.2 \mathrm{M})$ acetate buffer $\mathrm{pH} 4.8,0.3 \mathrm{ml}$ of $(0.4 \mathrm{M})$ sucrose solution $(0.4 \mathrm{M}$ sucrose solution in $0.2 \mathrm{M}$ Sodium Acetate buffer $\mathrm{pH} 4.8$ ) in $0.1 \mathrm{ml}$ of enzyme extract. In control tubes, sucrose was added only when enzyme preparation was inactivated by boiling for 5 min., after incubation at $30^{\circ} \mathrm{C}$ for $30 \mathrm{~min} .1$ $\mathrm{ml}$ of DNSA $(2.5 \mathrm{~g}$ of DNSA with $150 \mathrm{ml}$ distilled water containing $4.0 \mathrm{~g}$ of sodium hydroxide, $75 \mathrm{~g}$ of sodium potassium tartrate and made up the final volume up to $250 \mathrm{ml}$ with distilled water) was added to reaction mixture. Thereafter, tubes were placed in 
boiling water bath for $10 \mathrm{~min}$. and then cooled at room temperature. The entire sample was diluted to $5 \mathrm{ml}$ and absorbance was recorded at $560 \mathrm{~nm}$.

Sucrose synthase activity was assayed by the method ofHawker et al., (1976).

$0.2 \mathrm{~g}$ fresh leaf tissue was homogenized in 1.5 $\mathrm{ml}$ of ice cold $50 \mathrm{mM}$ sodium phosphate buffer, containing $\left(10 \mathrm{mM} \mathrm{MgCl}_{2}, 1 \mathrm{mM}\right.$ EDTA, $10 \mathrm{mM}$ ascorbic acid, $2.5 \mathrm{mM}$ DTT and $1 \mathrm{~g}$ Polyvinyl Polypyrrolidone), Centrifuged at $12,000 \mathrm{rpm}$ for 15 minutes at $4^{\circ} \mathrm{C}$ and supernatant used for assay. $0.5 \mathrm{ml}$ of $50 \mathrm{mMHepes}$ buffer $\mathrm{pH} 8.5$ containing $(15 \mathrm{mM}$ $\mathrm{MgCl}_{2}, 0.2 \mathrm{ml}$ of $10 \mathrm{mM}$ Fructose, $0.2 \mathrm{ml}$ of $10 \mathrm{mM}$ UDP-Glucose solution) in $0.1 \mathrm{ml}$ of enzyme extract, and incubated for $30 \mathrm{~min}$ at $30^{\circ} \mathrm{C}$. The reaction was stopped by adding $0.5 \mathrm{ml} 1 \mathrm{NNaOH}$. The concentrations of Sucrose Synthase were obtained by measuring optical density at $495 \mathrm{~nm}$.

$\alpha$ - Amylase activity was assayed by the method of Shuster and Gifford (1962).

$0.1 \mathrm{~g}$ fresh plant material was homogenized in $1.5 \mathrm{ml}$ ice cold extraction buffer $(.1 \mathrm{M}$ phosphate buffer $\mathrm{pH} 7$ ) and centrifuged at $40^{\circ} \mathrm{C}$ at $10,000 \mathrm{rpm}$ and supernatant was used as enzyme extract. $1 \mathrm{ml}$ of freshly prepare starch substrate $(150 \mathrm{mg}$ potato starch was

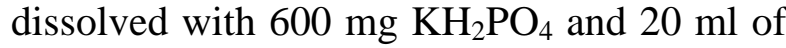
anhydrous $\mathrm{CaCl}_{2}$ in $100 \mathrm{ml}$ of distilled water, boiled for one minute, cooled and filter) was added to $0.5 \mathrm{ml}$ of enzyme extract. At zero time $0.2 \mathrm{ml}$ of aliquot was removed from this and $3 \mathrm{ml}$ of iodine solution (254 $\mathrm{mg} \mathrm{I}_{2}$ and 4 gm of KI dissolved in one liter of distillled water) was added. The absorbance was recorded at $620 \mathrm{~nm}$. Then the reaction mixture was incubated at $25^{\circ} \mathrm{C}$. Then after every 30 min. removed the aliquot and repeated the color developing process by adding iodine solution. The enzyme activity was expressed in terms of decreased in O.D at $620 \mathrm{~nm}$ per unit-time (min).

\section{Enzymes for Protein metabolism}

Nitrate reductase activity was estimated according to the method given by Bordon (1984).Leaf tissue was homogenized in cold $50 \mathrm{mM}$ phosphate buffer containing $0.5 \%$ $\mathrm{KNO}_{3}$ centrifuged at $12000 \mathrm{rpm}$ for 10 minute at $4^{\circ} \mathrm{C} .0 .3 \mathrm{ml}$ of extract was treated with 0.2 $\mathrm{ml} 1 \%$ Sulphanilamide and $0.5 \mathrm{ml} 5 \%$ (1Napthyl)-ethylene diamine and left at room temperature for 20 minute. The absorbance was recorded at $542 \mathrm{~nm}$.

Protease activity was assayed using the method of Ainous (1970). leaf tissue was homogenized in cold $50 \mathrm{mM}$ phosphate buffer contanin $1 \% \mathrm{NaCl}$ centrifuged at $12000 \mathrm{rpm}$ for 10 minute at $4^{\circ} \mathrm{C} .0 .2 \mathrm{ml}$ supernatant was treated with $0.2 \mathrm{ml} 1 \%$ Casein and $0.4 \mathrm{ml}$ of $40 \%$ TCA solution and then $0.2 \mathrm{ml}$ of $0.5 \%$ Folin phenol reagent were added and absorbance was recorded at 570nm.

\section{Data analysis}

The data were determined by the one way analysis of variance (ANOVA), the design was completely randomized design (CRD). Data analysis was carried out using SPSS software. Vertical bar represent standard error.

\section{Results and Discussion}

The one way analysis of variance (ANOVA) for all data determined that there were highly significant variation between both varieties $(\mathrm{P}<0.01)$. According to (table 1-5) the marginal mean of the RD2052 and RD2552 treated with AA showed highest root length, shoot length and plant height compared to unprimed and SA primed seedlings. These results indicate that both $\mathrm{AA}$ and SA were ameliorating the $\mathrm{Al}$ affect successfully but AA priming was more effective in ameliorating the stress. These results 
confirmed the earlier statistical analysis that primary target of Al toxicity are roots and similar observations were observed in maize (Bell and Edward, 1986) and barley (Foy, 1996). The present results of barley seedling parameters grown under $\mathrm{Al}$ are in agreement with the reports on maize (Malekzadeh et al., 2015), Rice (Bidhan and Sanjib, 2014) and Flax (Saritha and Vasantha, 2016). All these studies reported drastic effects of $\mathrm{Al}$ on various growth parameters.

AA and SA both are self produced in plant, play crucial role in plant growth, also show ameliorative effect against various biotic and abiotic stresses. Similar observations were reported by Wang et al., (2014) in Tomato seedling where Salicylic acid (SA) ameliorated its toxicity through activation of antioxidant system. Batool et al., (2012) reported stimulatory effect of Ascorbic acid (AA) on sugarcane seedlings.

The photosynthetic pigments ( $\mathrm{Chl} \mathrm{a}, \mathrm{Chl} \mathrm{b}$, Total Chlorophyll, Carotenoid) content significantly decreased, while Anthocyanin content increased with increased Aluminum concentration (graph 1-5). The more declined photosynthetic pigments were recorded in RD2052 barley variety that depicts its susceptible nature in comparison to RD2552 tolerant variety. Similar results of Al toxicity on photosynthetic pigments have been reported in Citrus (Jiang et al., 2009) and Brassica napus (Zahra et al., 2015). Pereira et al., (2006) showed that, Al caused decrease in Chl synthesis by inhibiting the activity of aminolevulinic acid (ALA) dehydratase enzyme responsible for the formation of monopyrroleporphobilonogen, which is a part of the Chlmolecule as well as the cytochromes and also impaired plant growth. Vetorello et al., (2005) also reported that $\mathrm{Al}$ toxicity resulted in declined chlorophyll content due to cellular and ultrastructural modifications of leaves, reduction of stomatal opening, decreased photosynthetic activity, chlorosis and leaf necrosis. Priming with AA and SA PGRs ameliorated the adverse effects of Al toxicity and resulted in the maintained Photosynthetic pigments. Comparable results have been reported for SA and AA applications in various other crop plants e.g., Sorghum (Mahendranath et al., 2012), Tomato (Varalakshmi et al., 2014) and Flax (Belkhadi et al., 2010). Salicylic acid was reported to protect photosynthesis and stomatal regulation of plant under salinity and drought stress (Arfan et al., 2007). Zhou et al., (1999) reported that photosynthetic pigments increased in corn with SA application.

Increased Anthocyanin concentrations were observed in RD2052 than RD2552 at high Al concentration. Comparable results were reported in Vigna radiata (Sevugaperumal et $a l ., 2012$ ) for high anthocyanin content under Al toxicity. Anthocyanins are water-soluble pigment which exhibits defense against ultraviolet radiation, herbivores, drought and cold temperatures (Hatier and Gould, 2008). Priming with SA and AA, mitigated the Al effect and further improved the Anthocyanin content. Decreased photosynthetic pigments lead to the impaired photosynthesis and this may lead to the declined assimilation product concentration.

According the graph no.6-7 the total sugar and reducing sugar concentration decreased significantly with increased $\mathrm{Al}$ concentration. The decrease in total sugar and reducing sugar content was more in susceptible (RD2052) barley variety in comparison to tolerant (RD2552) barley variety with aluminum treatment at $6 \mathrm{mMconcentration.} \mathrm{Similar}$ findings were reported in Barely (Abdalla, 2008) and Sunflower (Najmeh et al., 2014) that decline in sugar content with increase in Al concentrations. Sugar content in AA and SA primed seedlings of both varieties showed better results than unprimed with less 
decreasing percentage. In both RD2052 and RD2552 primed with AA showed highest sugar content at control in comparison to unprimed and SA primed barley varieties. Amira and Abdul (2014) reported that ascorbic acid treatments improved plant tolerance against water stress and sugars approached near its normal condition. Increasing amount of sugars and thus the osmosis gradient in plant tissues treated with ascorbic acid would lead to the resistance against loosing water, protect chloroplasts and accelerate plant growth under stress conditions in Okra (Amin et al., 2009). Similarly, mitigating effects of SA was discussed by Umebese and Fabiyi (2015), who reported that Aluminum decreased total sugar content but SA significantly alleviated Al toxicity and maintain total sugar content in Abelmoschuses culentus var.

Free amino acid concentration increased significantly with imposed Al toxicity. The free amino acid in susceptible variety (RD2052) increased up to $60.6 \%$ and in tolerant (RD2552) increase was up to $51.75 \%$ with aluminum treatment at $6 \mathrm{mM}$ concentration compared with control (graph no.8). In the same way it was noticed that AA primed RD2052 showed $42.15 \%$ increased, while RD2552 AA primed showed $26.63 \%$ increase, similarly SA primed RD2052 showed $38.86 \%$ increase, while SA primed RD2552 showed $20.33 \%$ increase at $6 \mathrm{mM}$ Aluminum concentration compared to control. According to Luma et al., (2016) increased in total soluble amino acid content may have probably been caused by the increase in the activity of proteases enzyme, which break the reserve proteins according to the exposition of a plant to any injury, in this case the effect of aluminum toxicity. Treatment with AA and SA less increased concentration of free amino acid was noticed compared to unprimed variety. AA and SA alleviated the Al toxic effect by regulating the protease activity in comparison to umprimed. AA and SA cause accumulation amino acid under stress through maintaining an enhanced level of ABA in seedlings (Hamada et al., 2000; Hameda and Ahmed, 2013). Total soluble Protein content (graph no.9) decreased significantly with increased Aluminum concentration. The susceptible variety RD2052 showed highest decrease\% (64.96\%) in Protein content, while in tolerant RD2552 it was $41.46 \%$ under aluminum treatment at $6 \mathrm{mM}$ concentration. According to Cruz et al., (2011) during the stress caused by aluminum, this element acts as a limiting factor for the assimilation of nitrogen, once there is a reduction in the nitrate reductase activity, and the low supply of nitrogen would cause a reduction in the synthesis of protein. With AA and SA priming the decrease in the total protein content was comparatively less at different $\mathrm{Al}$ levels compared to unprimed seedling. Dolatabadian et al., (2010) reported that ascorbic acid scavenged reactive oxygen species and prevented protein oxidation and degradation. Azooz et al., (2011) reported an increase in soluble proteins, due to foliar spray with SA leading to increase in broad bean growth.

Invertase, Sucrose synthase and $\alpha$-Amylase was significantly decreased in both verities RD2052 and RD2552with increased Aluminum concentration (graph no. 10-12), but susceptible variety showed more reduction of all three enzymes than tolerant over control at $6 \mathrm{mM}$ aluminum treatment, But AA and SA treatment improved the activity and proved that they alleviate Al toxicity, So both primed varieties performed better and showed less decreased enzyme Invertase, Sucrose synthase and $\alpha$-Amylase activity at $6 \mathrm{mM}$ Aluminum concentration. Similar results were observed in tomato (Simon et al., 1994); barley (Mona, 2008); rice (Muthukumaran and Vijaya, 2014) against aluminum toxicity. 
Table.1 Effect of different concentrations of Aluminum on Root length (cm) of RD2052 and RD2552 with and without AA and SA treatment at $\mathrm{pH} 4$

\begin{tabular}{|l|c|c|c|c|c|c|}
\hline VarXConc & C0 & $\mathbf{2 m M}$ & $\mathbf{4 m M}$ & $\mathbf{6 m M}$ & Var.Mean & Decrease\% \\
\hline RD2052 & 9.82 & 5.50 & 4.04 & 3.03 & 5.61 & 69.14 \\
\hline RD2052AA & 10.72 & 9.01 & 7.98 & 6.03 & 8.44 & $\mathbf{4 3 . 7 5}$ \\
\hline RD2052SA & $\mathbf{1 0 . 9 7}$ & 8.59 & 6.21 & 5.42 & 7.80 & 50.63 \\
\hline RD2552 & 7.40 & 5.33 & 4.27 & 3.21 & 5.05 & 56.62 \\
\hline RD2552AA & $\mathbf{9 . 8 8}$ & 9.06 & 7.48 & 6.54 & 8.25 & $\mathbf{3 3 . 8 1}$ \\
\hline RD2552SA & 8.67 & 7.83 & 6.25 & 5.66 & 7.1 & 34.72 \\
\hline Conc. Mean & $\mathbf{9 . 5 7}$ & 7.55 & 6.04 & 4.93 & 7.06 & \\
\hline \multicolumn{6}{|l|}{ S.Em \pm 0.19} & \multicolumn{6}{|l}{ C.D.5\%=0.53 } & C.V\%=9.16 & P=2.231E-18 \\
\hline
\end{tabular}

Table.2 Effect of different concentrations of Aluminum on Shoot length (cm) of RD2052 and RD2552 with and without AA and SA treatment at pH4

\begin{tabular}{|c|c|c|c|c|c|c|}
\hline VarXConc & $\mathrm{CO}$ & $2 \mathrm{mM}$ & $4 \mathrm{mM}$ & $6 \mathrm{mM}$ & Var. Mean & Decrease \% \\
\hline RD2052 & 11.57 & 9.22 & 6.29 & 5.66 & 8.18 & 51.08 \\
\hline RD2052AA & 12.77 & 11.15 & 9.18 & 8.43 & 10.38 & 34.01 \\
\hline RD2052SA & 12.36 & 10.43 & 8.93 & 7.36 & 9.52 & 35.21 \\
\hline RD2552 & 7.85 & 6.20 & 5.06 & 4.63 & 5.94 & 41.02 \\
\hline RD2552AA & 10.32 & 10.05 & 7.81 & 7.22 & 8.85 & 30.04 \\
\hline RD2552SA & 9.13 & 8.62 & 7.57 & 6.93 & 8.06 & 24.1 \\
\hline Conc. Mean & 10.50 & 9.28 & 7.47 & 6.71 & 8.5 & \\
\hline \multicolumn{2}{|c|}{ S.Em \pm 0.22} & \multicolumn{2}{|c|}{ C.D.5\% $=0.61$} & C.V\% $=9.7$ & \multicolumn{2}{|c|}{$\mathbf{P}=2.311 \mathrm{E}-20$} \\
\hline
\end{tabular}

Table.3 Effect of different concentrations of Aluminum on Plant height $(\mathrm{cm})$ of RD2052 and RD2552 with and without AA and SA treatment at pH4

\begin{tabular}{|l|c|c|c|c|c|c|}
\hline \multicolumn{1}{|c|}{ VarXConc } & C0 & $\mathbf{2 m M}$ & $\mathbf{4 m M}$ & $\mathbf{6 m M}$ & Var.Mean & Decrease \% \\
\hline RD2052 & 21.06 & 14.72 & 10.33 & 8.69 & 13.7 & 58.74 \\
\hline RD2052AA & $\mathbf{2 3 . 4 9}$ & 20.17 & 17.16 & 14.46 & 18.82 & $\mathbf{3 8 . 4 4}$ \\
\hline RD2052SA & 23.33 & 19.02 & 15.14 & 12.78 & 17.32 & 42.74 \\
\hline RD2552 & 15.01 & 11.53 & 9.33 & 7.84 & 10.93 & 47.77 \\
\hline RD2552AA & $\mathbf{2 0 . 2 0}$ & 19.11 & 15.30 & 13.76 & 17.09 & 31.9 \\
\hline RD2552SA & 17.79 & 16.45 & 14.82 & 12.6 & 15.42 & $\mathbf{2 9 . 1 7}$ \\
\hline Conc. Mean & 19.98 & 16.83 & 13.68 & 11.7 & 15.55 & \\
\hline \multicolumn{6}{|c|}{ S.Em \pm 0.26} & \multicolumn{6}{|c|}{ C.D.5\%= 0.75} & C.V\% $=5.95$ & \multicolumn{2}{c|}{ P=2.203E-25 } \\
\hline
\end{tabular}


Table.4 Effect of different concentrations of Aluminum on Fresh matter (g) of RD2052 and RD2552 with and without AA and SA treatment at $\mathrm{pH} 4$

\begin{tabular}{|c|c|c|c|c|c|c|}
\hline VarXConc & $\mathrm{CO}$ & $2 \mathrm{mM}$ & $4 \mathrm{mM}$ & $6 \mathrm{mM}$ & Var. Mean & Decrease \% \\
\hline RD2052 & 0.653 & 0.433 & 0.327 & 0.250 & 0.416 & 61.72 \\
\hline RD2052AA & 0.823 & 0.737 & 0.603 & 0.523 & 0.672 & 36.45 \\
\hline RD2052SA & 0.803 & 0.703 & 0.623 & 0.482 & 0.653 & 40.1 \\
\hline RD2552 & 0.520 & 0.457 & 0.357 & 0.3 & 0.408 & 42.31 \\
\hline RD2552AA & 0.637 & 0.597 & 0.517 & 0.450 & 0.550 & 29.36 \\
\hline RD2552SA & 0.597 & 0.550 & 0.463 & 0.410 & 0.505 & 31.32 \\
\hline Conc. Mean & 0.672 & 0.579 & 0.482 & 0.402 & 0.534 & \\
\hline \multicolumn{2}{|c|}{ S.Em \pm 0.008} & \multicolumn{2}{|c|}{ C.D.5\% $=0.021$} & C.V\% $=4.864$ & \multicolumn{2}{|c|}{$\mathbf{P}=2.121 \mathrm{E}-32$} \\
\hline
\end{tabular}

Table.5 Effect of different concentrations of Aluminum on Dry matter (g) of RD2052 and RD2552 with and without AA and SA treatment at pH4

\begin{tabular}{|c|c|c|c|c|c|c|}
\hline Means & $\mathrm{CO}$ & $2 \mathrm{mM}$ & $4 \mathrm{mM}$ & $6 \mathrm{mM}$ & Var. Mean & Decrease \% \\
\hline RD2052 & 0.073 & 0.053 & 0.037 & 0.03 & 0.048 & 58.9 \\
\hline RD2052AA & 0.107 & 0.087 & 0.073 & 0.064 & 0.083 & 40.2 \\
\hline RD2052SA & 0.103 & 0.083 & 0.063 & 0.056 & 0.076 & 45.63 \\
\hline RD2552 & 0.077 & 0.057 & 0.043 & 0.037 & 0.054 & 51.94 \\
\hline RD2552AA & 0.093 & 0.093 & 0.07 & 0.066 & 0.078 & 29.03 \\
\hline RD2552SA & 0.087 & 0.077 & 0.064 & 0.058 & 0.072 & 33.33 \\
\hline Conc. Mean & 0.090 & 0.075 & 0.058 & 0.052 & 0.068 & \\
\hline \multicolumn{2}{|c|}{ S.Em \pm 0.002} & \multicolumn{2}{|c|}{ C.D.5\% $=0.005$} & C.V\% $=8.496$ & \multicolumn{2}{|c|}{$\mathbf{P}=2.433 \mathrm{E}-21$} \\
\hline
\end{tabular}

Graph.1 Chl a (mg g-1FW) in RD2052 and RD2552 Barley varieties (unprimed and primed with AA and SA) germinated under different concentrations of Aluminum at pH4

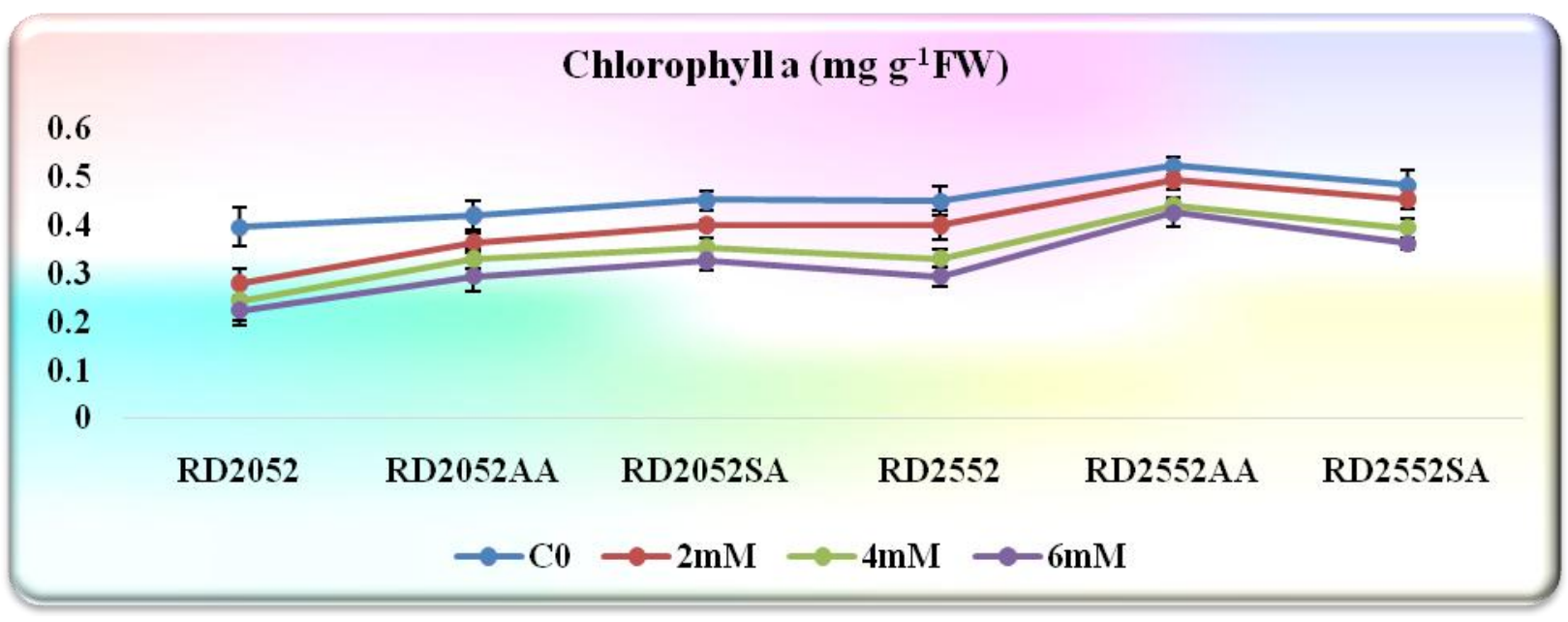


Graph.2 Chl b (mg g-1FW) in RD2052 and RD2552 Barley varieties (unprimed and primed with AA and SA) germinated under different concentrations of Aluminum at pH4

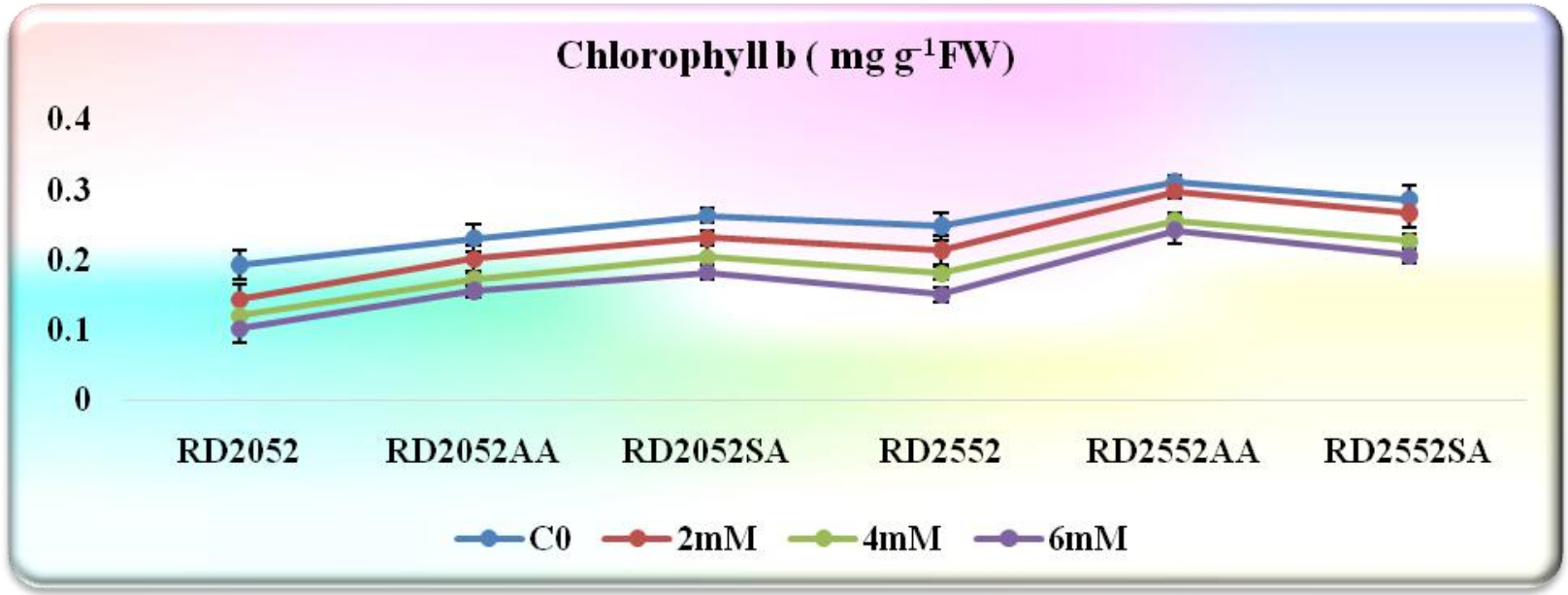

Graph.3 Total Chlorophyll (mg g-1FW) in RD2052 and RD2552 Barley varieties (unprimed and primed with AA and SA) germinated under different concentrations of Aluminum at $\mathrm{pH} 4$

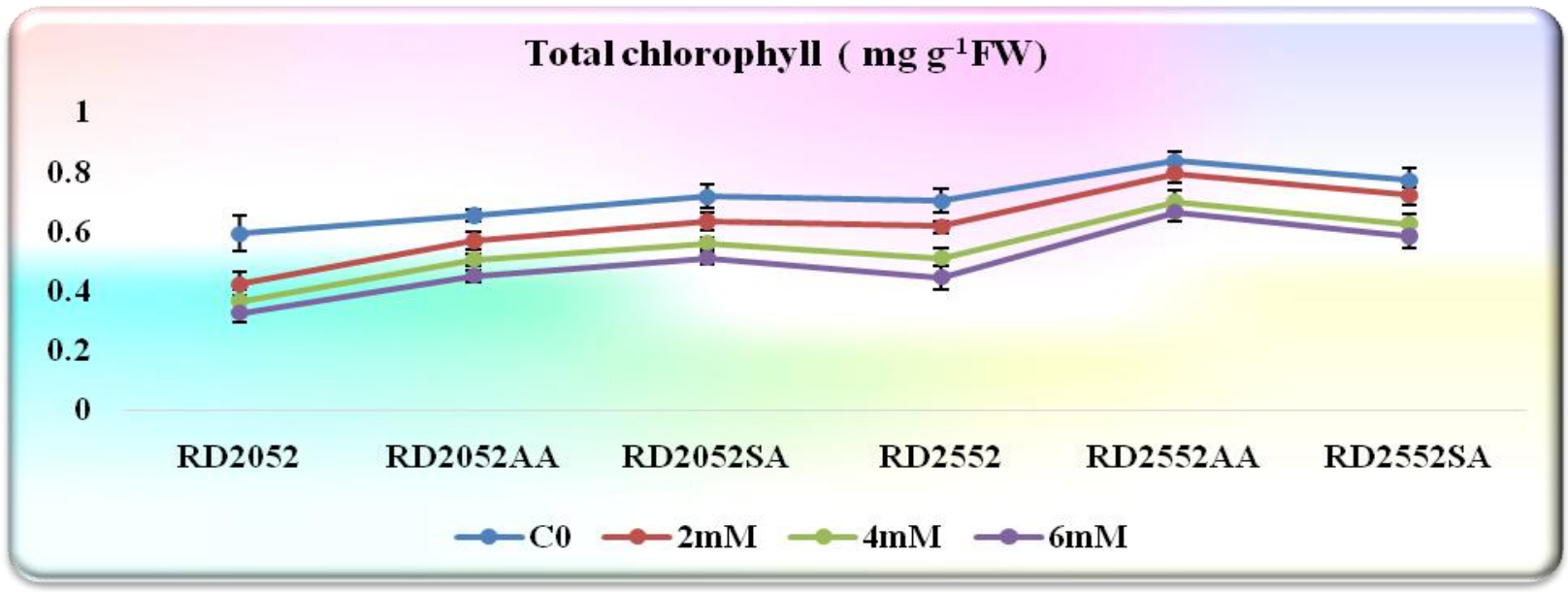

Graph.4 Carotenoid (mg g-1FW) in RD2052 and RD2552 Barley varieties (unprimed and primed with AA and SA) germinated under different concentrations of Aluminum at $\mathrm{pH} 4$

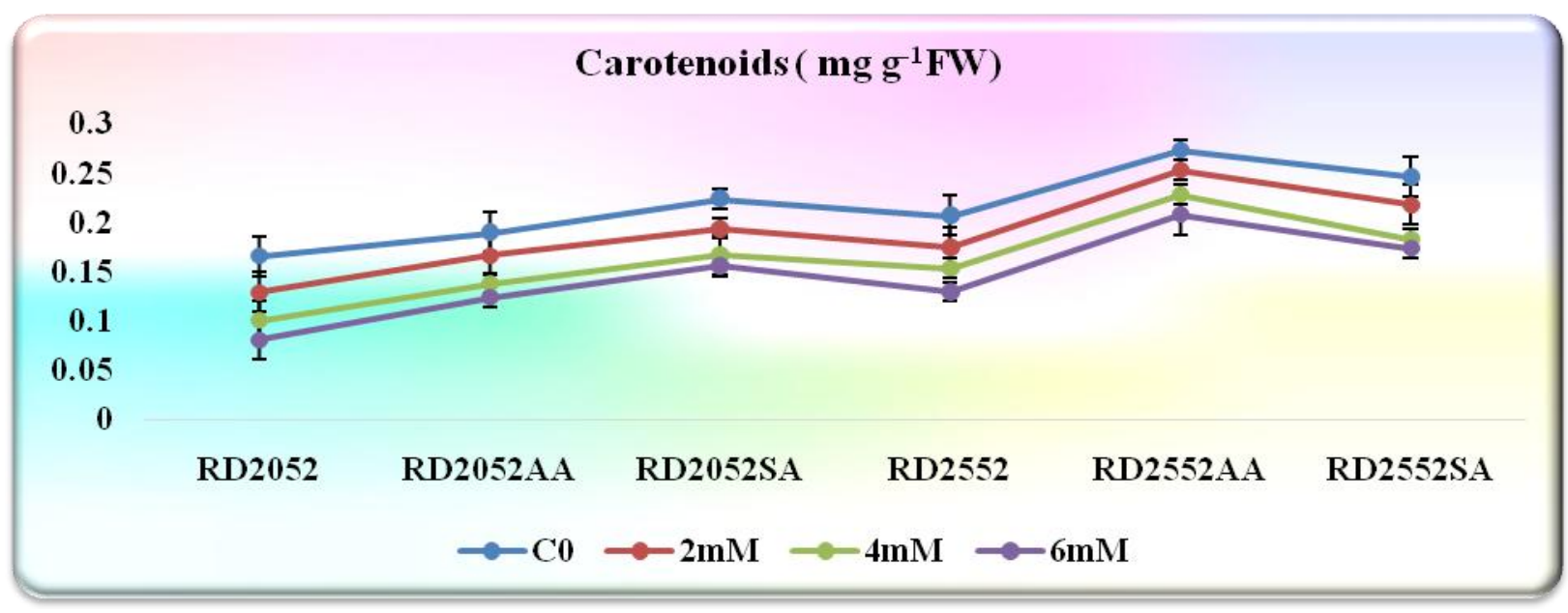


Graph.5 Anthocyanin ( $\mu \mathrm{g}$ g-1FW) in RD2052 and RD2552 Barley varieties (uprimed and primed with AA and SA) germinated under different concentrations of Aluminum at pH4

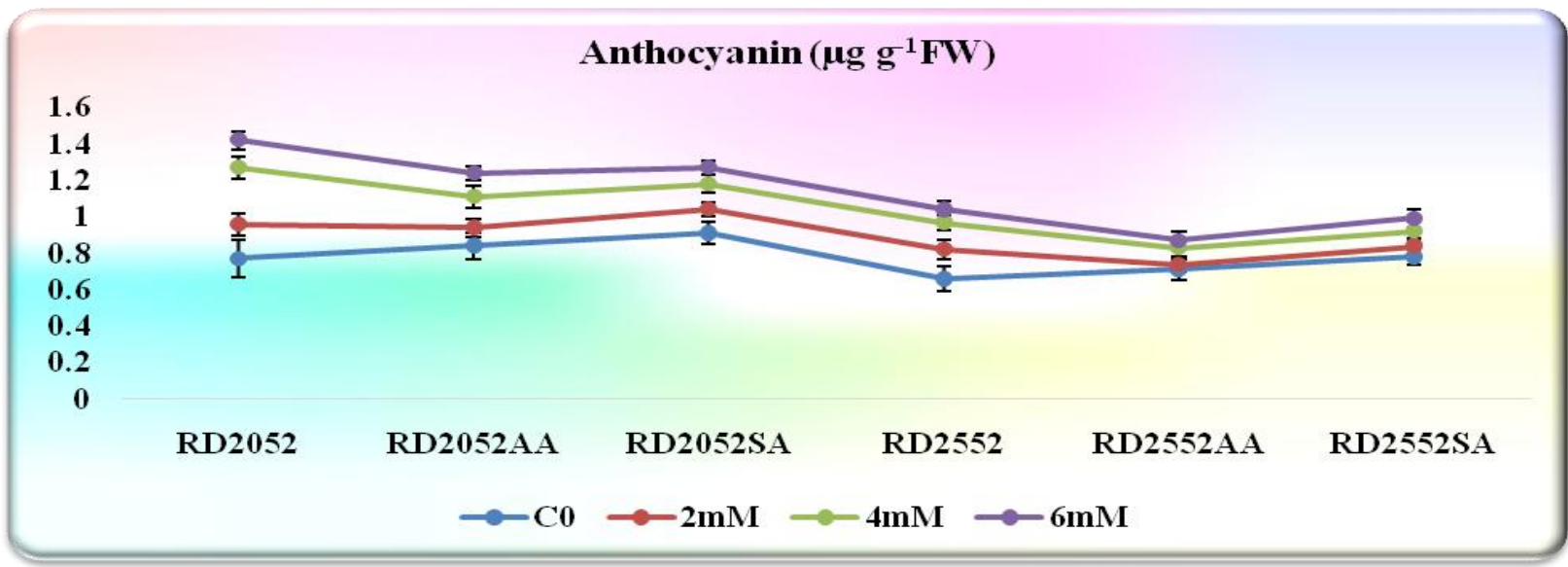

Graph.6 Total sugar (mg g-1DM) in RD2052 and RD2552 Barley varieties (unprimed and primed with AA and SA) germinated under different concentrations of Aluminum at pH4.

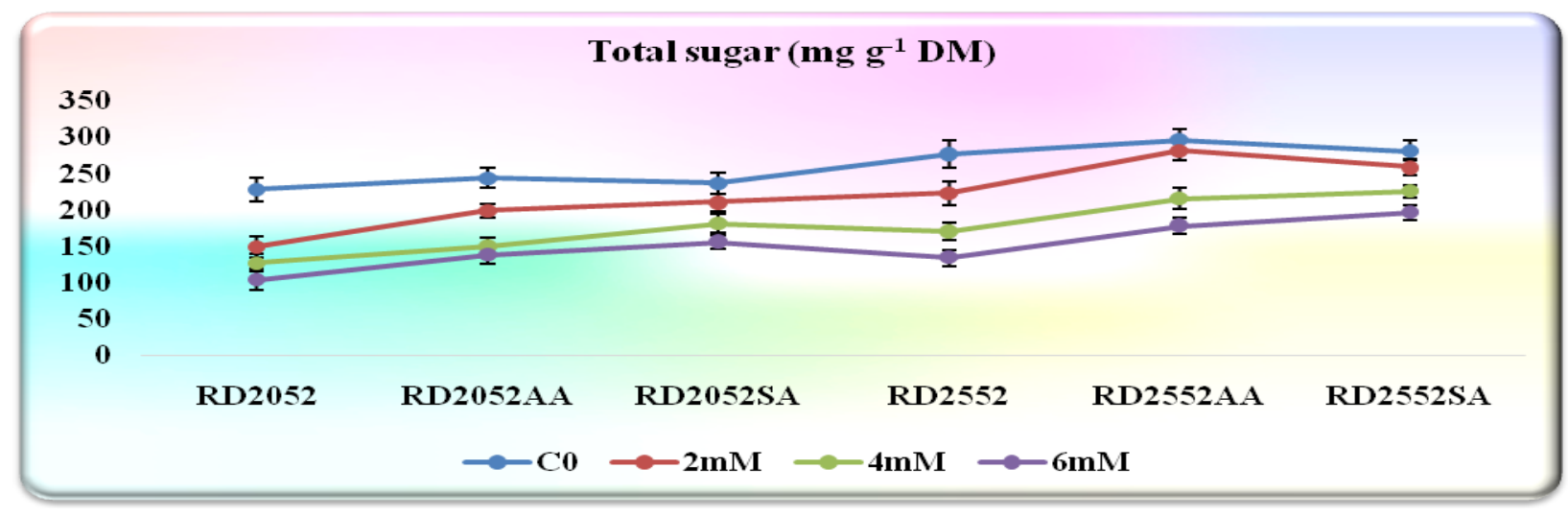

Graph.7 Reducing sugar content (mg g-1DM) in RD2052 and RD2552 Barley varieties (unprimed and primed with AA and SA) germinated under different concentrations of Aluminum at $\mathrm{pH} 4$

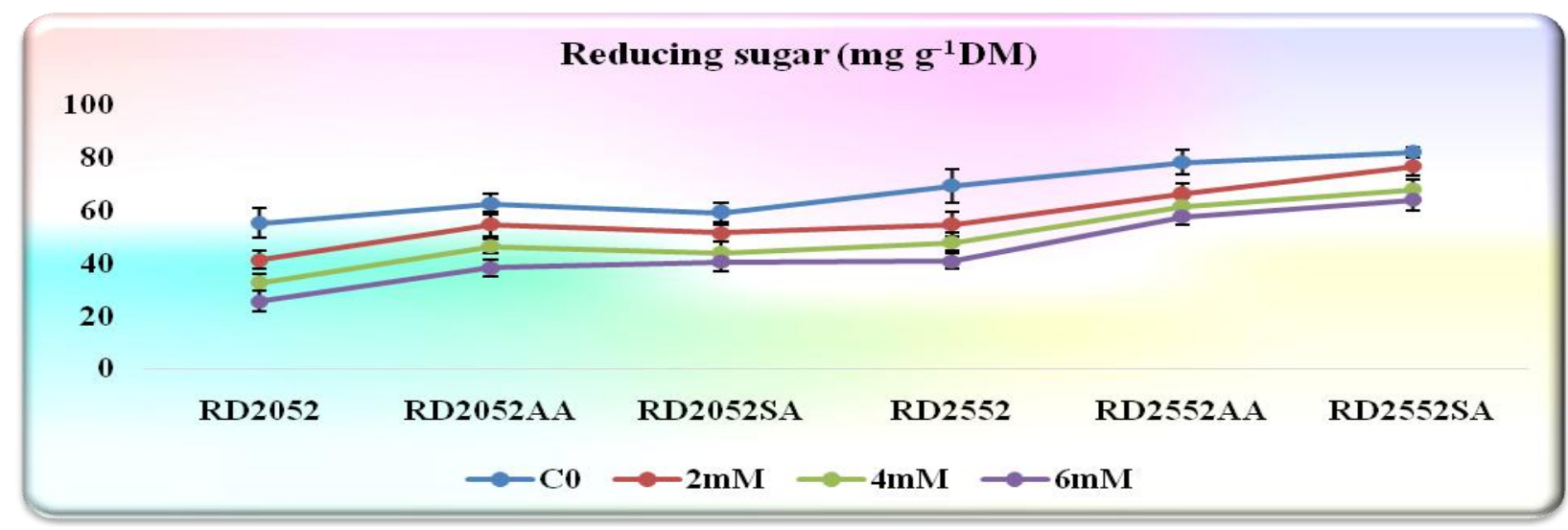


Graph.8 Free amino acid (mg g-1DM) in RD2052 and RD2552 Barley varieties (unprimed and primed with AA and SA) germinated under different concentrations of Aluminum at pH4

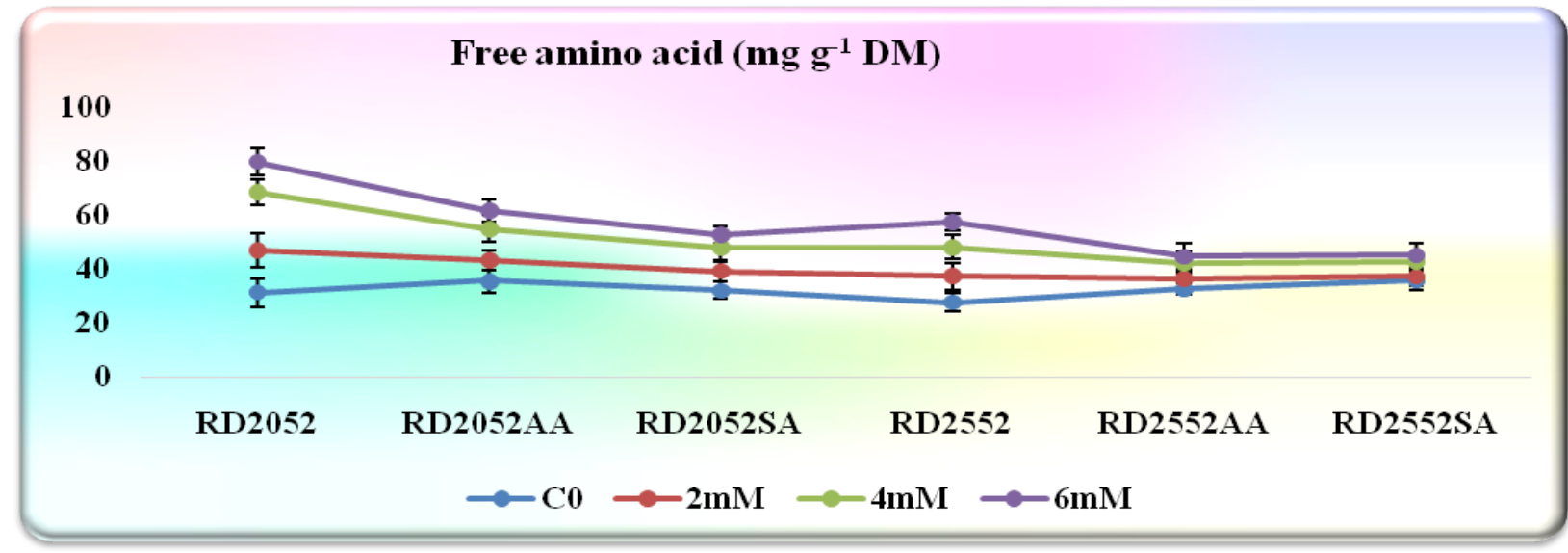

Graph.9 Protein (mg g-1FW in RD2052 and RD2552 Barley varieties (unprimed and primed with AA and SA) germinated under different concentrations of Aluminum at pH4

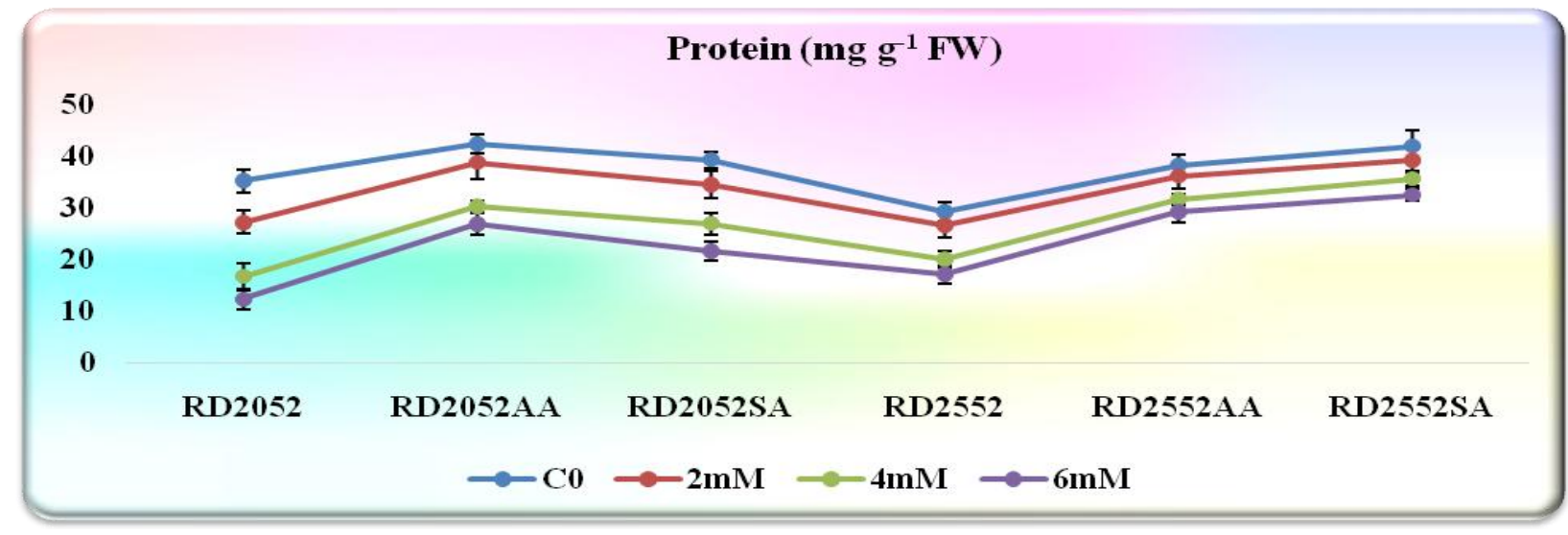

Graph.10 Invertase activity (nM sucrose g-1 FW min-1) in RD2052 and RD2552 Barley varieties (unprimed and primed with AA and SA) germinated under different concentrations of Aluminum at $\mathrm{pH} 4$

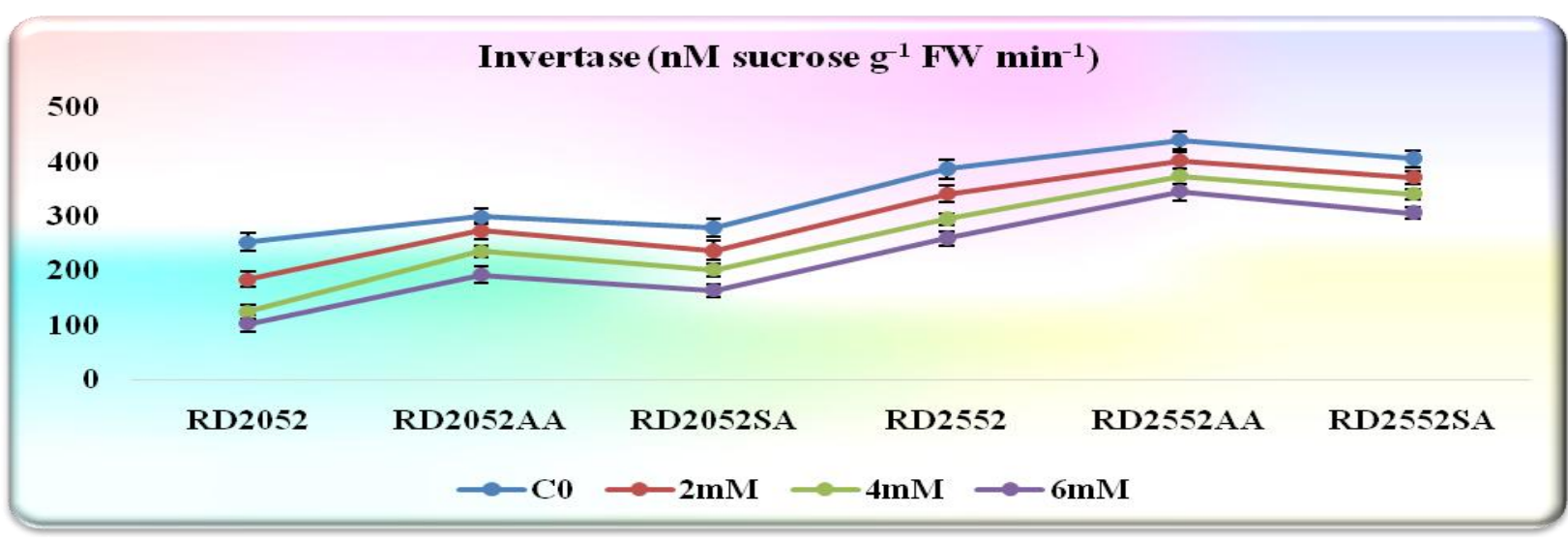


Graph.11 Sucrose synthase (nMsucrose g-1 FW min-1) in RD2052 and RD2552 Barley varieties (unprimed and primed with AA and SA) germinated under different concentrations of Aluminum at $\mathrm{pH} 4$

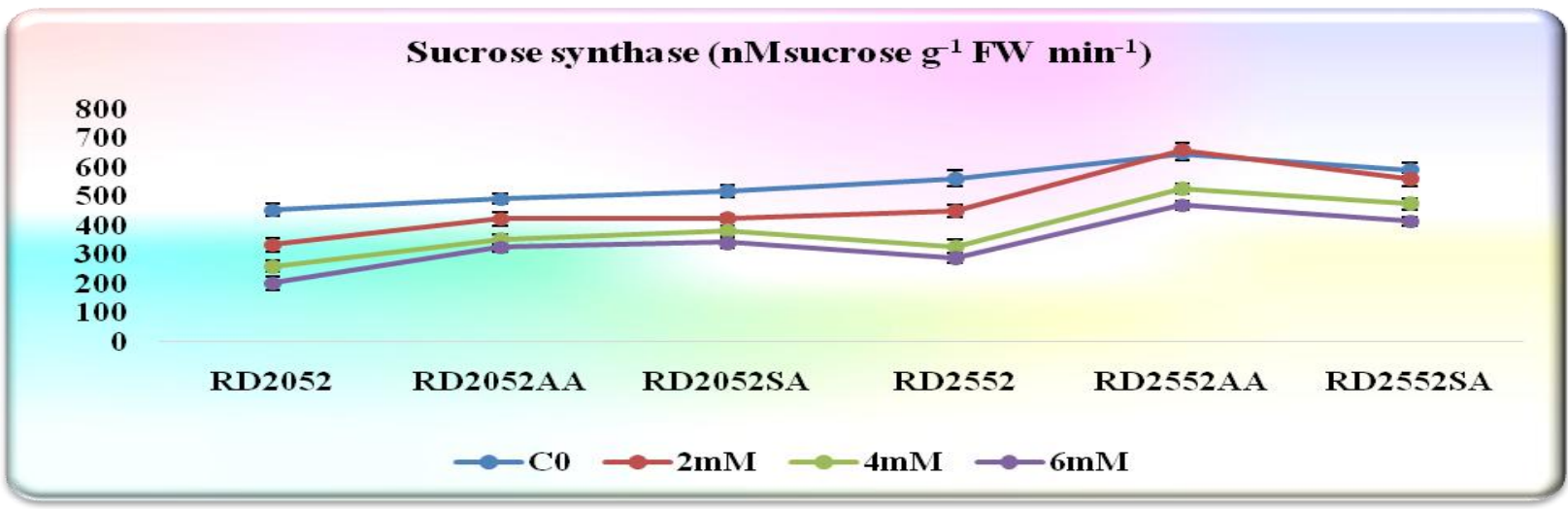

Graph.12 $\alpha$-Amylase (mg Maltose hr-1mg-1Protein) in RD2052 and RD2552 Barley varieties (unprimed and primed with AA and SA) germinated under different concentrations of Aluminum at $\mathrm{pH} 4$

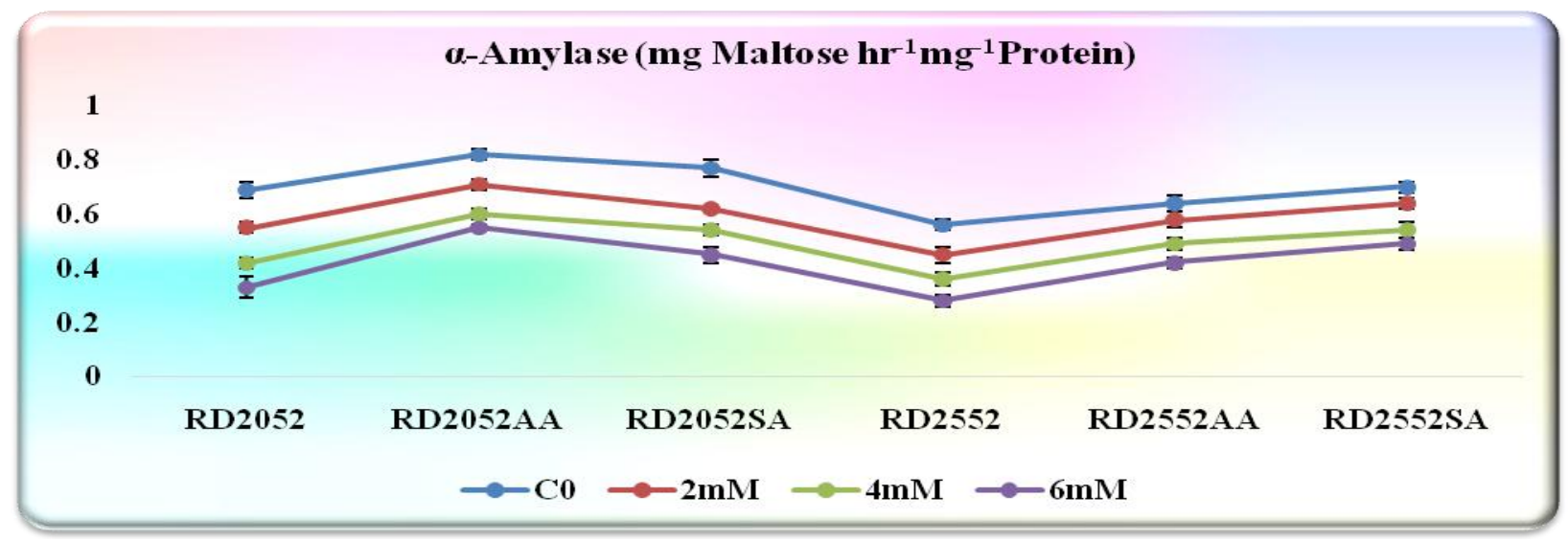

Graph.13 Nitrate Redutase activity ( $\mu \mathrm{MNO} 2-\mathrm{g}-1 \mathrm{~h}-1)$ in RD2052 and RD2552 Barley varieties (unprimed and primed with AA and SA) germinated under different concentrations of Aluminum at $\mathrm{pH} 4$

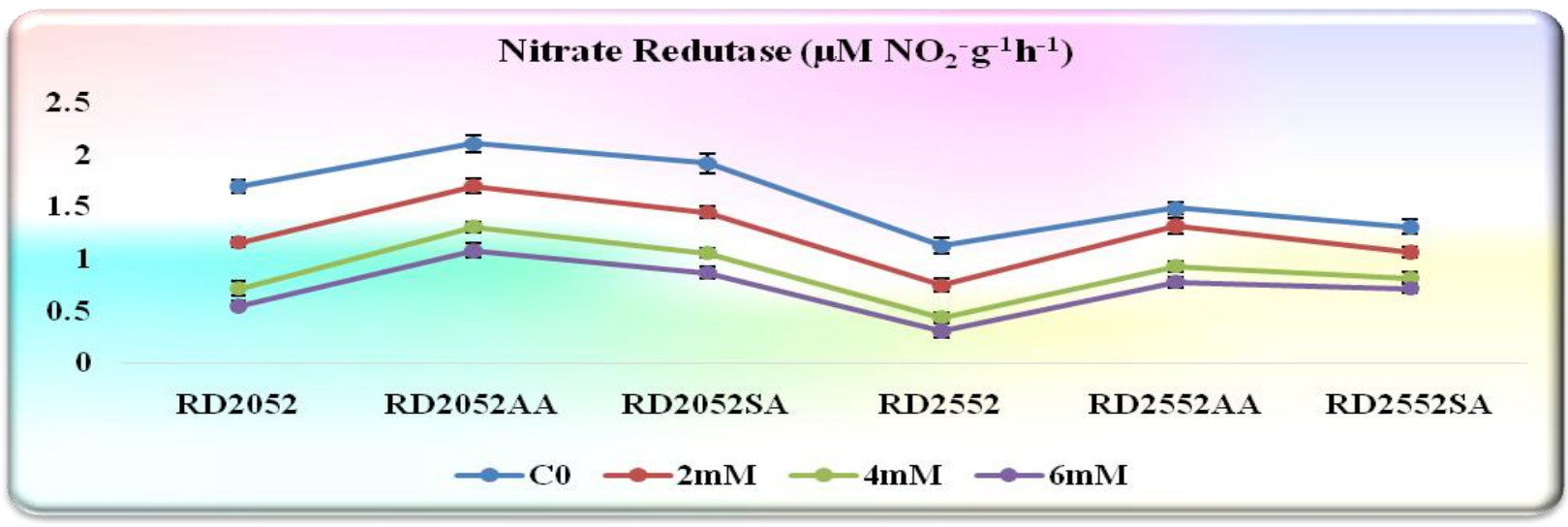


Graph.14 Protease activity ( $\mu \mathrm{M}$ g-1FW) in RD2052 and RD2552 Barley varieties (unprimed and primed with AA and SA) germinated under different concentrations of Aluminum at $\mathrm{pH} 4$

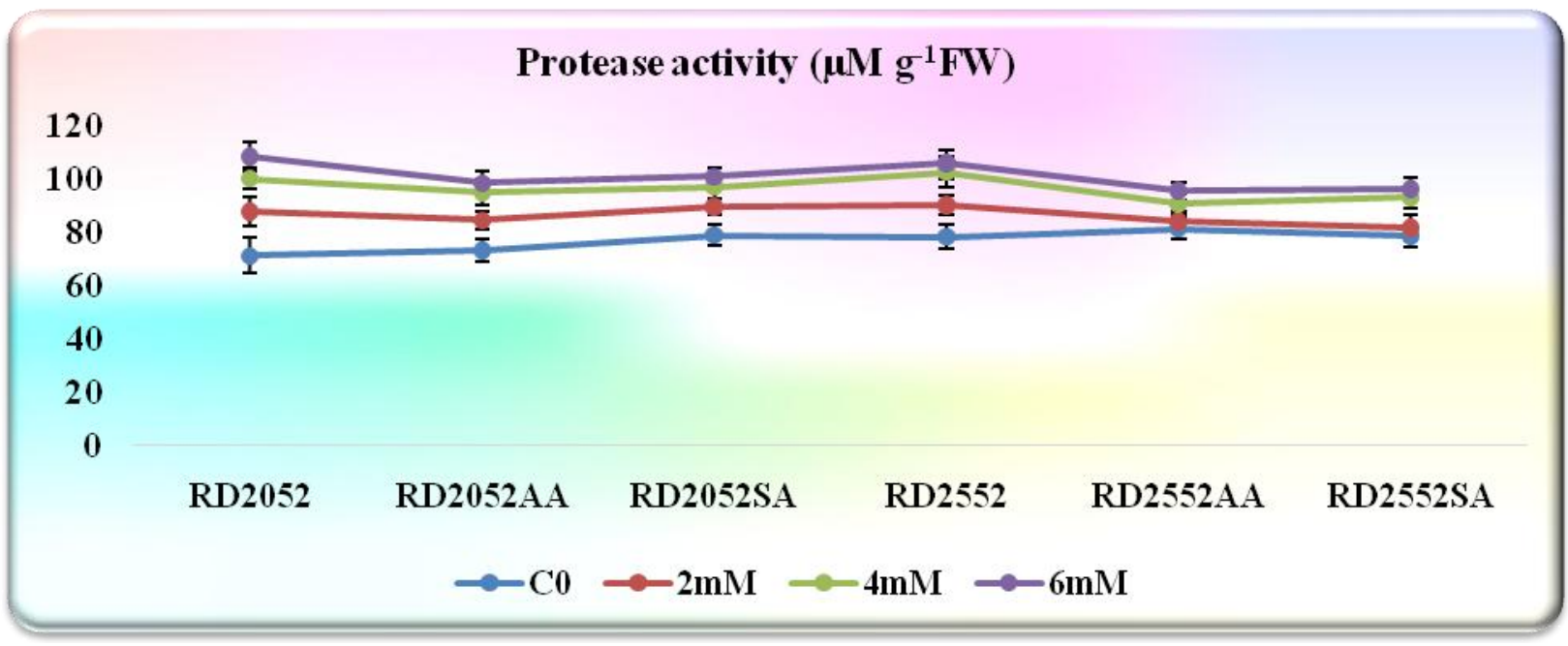

According to the graph no.13 the Nitrate Redutase activity decreased significantly with increased Aluminum concentration. At the highest $\mathrm{Al}$ concentration $(6 \mathrm{mM})$, minimum Nitrate Redutase activity was observed in susceptible (RD2052) barley variety. NR is the first enzyme in the $\mathrm{NO}_{3}$ assimilation pathway and probably represents the rate limiting step in this process and generates $\mathrm{NO}_{2}$ in the cytoplasm of a plant cell, which is translocated into the plastids for further reduction and metabolization (Kaiser et al., 1999; Mazid et al., 2010). Sharma and Dubey (2005) reported that high acidity in the soil can also cause inhibition of nitrate reductase activity. NR primed with AA and SA performed better in comparison to unprimed in both barley varieties.

Protease activity increased with increased Aluminum concentration in both barley seedlings (graph no.14). The present result agreement Muthukumaran and Vijaya (2014) reported that elevated protease activity under aluminum stress points to enhanced proteolysis in two Rice varieties. Hydrolysis of proteins by proteases releases amino acids which can use for storage and/or transport and for osmotic adjustment during stress in seedlings (Palma et al., 2002). The amino acid pool enlargement in the stressed plants can be attributed to a decreased protein synthesis and enhanced proteolysis (Parida et al., 2004). Proteolysis is also allied to oxidative stress results by $\operatorname{ROS}\left(\mathrm{O}_{2}{ }^{-}, \mathrm{H}_{2} \mathrm{O}_{2}\right.$, and $\mathrm{OH}^{-}$) whereas oxidative stress can modified the protein which is characterized for the production of carbonyl groups in the molecules (Azmat et al., 2007; Umebese and Motajo, 2008). Protease activity in barley seedlings primed with AA and SA showed constant protease activity in comparison to unprimed barley varieties.

In conclusion, the present study was aimed to mitigate the Al toxic effect with the help of two plant growth regulators viz., AA and SA seed priming. Analysis of all the parameters (Seedlings, photosynthetic, biochemical, enzymes of carbohydrate metabolism and protein metabolism) showed that both plant growth regulator successfully ameliorate $\mathrm{Al}$ toxic effect in both barley varieties, and RD2052 performed as susceptible while RD2552act as tolerant Barley species under Al stress. 


\section{References}

Abdalla, M.M. 2008. Physiological aspects of aluminum toxicity on some metabolic and hormonal contents of Hordeumvulgare seedlings. Aust. J. Basic App. Sci., 2: 549-560.

Ainous, I.L. 1970. Preliminary studies on proteins of Vignasinesis. Ann. Accad. Bvas Ciemc., 42: 97-101.

Alvarez, I., Sam, O., Reynaldo, I., Testillano, P., Risueno, M.C. and Arias, M. 2012 Morphological and cellular changes in rice roots Oryza sativa $\mathrm{L}$ caused by $\mathrm{Al}$ stress. Bot. Studies, 53: 67-73

Amin, B., Mahleghah, G., Mahmood, H.M.R. and Hossein, M. 2009. Evaluation of interaction effect of drought stress with ascorbate and salicylic acid on some of physiological and biochemical parameters in okra (Hibiscus esculentus L.). Res. J. Biol. Sci., 4: 380-387.

Amira, M.S. and Abdul, Q. 2014. Effect of Ascorbic Acid antioxidant on Soybean (Glycine max L.) plants grown under water stress conditions. Int. J. Adv. Res. Biol. Sci., 1(6): 189-205.

Ansari, O. and Sharif-Zadeh, F. 2012. Osmo and hydro priming improvement germination characteristics and enzyme activity of Mountain Rye (Secalemontanum) seeds under drought stress. J. Stress Physiol. Biochem., 8(4): 253- 261.

Arfan, M., Athar, H. and Ashraf, M. 2007. Does exogenous application of salicylic acid through the rooting medium modulate growth and photosynthetic capacity in two differently adapted spring wheat cultivars under salt stress?

J. Plant Physiol., 164: 685-694.

Azmat, R., Hasan, S. and Fahimuddin. 2007. Aluminum stress induced alteration in seedling growth and alleviation in protein and amino acid contents of Lens culinaris. Asian J. Plant Sci., 6(8):
1246-1250.

Azmat, R., Noshab, Q., Hajira, N. B., Raheela, N., Fahimuddin and Mustafa, K. 2015. Aluminum induced enzymatic disorder as an important eco biomarker seedling of Lens culinaris medic. Pak. J. Bot., 47(1): 89-93.

Azooz, M.M., Youssef, A.M. and Parvaiz, A. 2011. Evaluation of salicylic acid (SA) application on growth, osmotic solutes and antioxidant enzyme activities on broad bean seedlings grown under diluted seawater. Int. J. Plant Physiol. Biochem., 3(14): 253-264.

Batool, E., Zahoor, A.S. and Faheem, A. 2012. Effect of exogenous application of ascorbic acid on antioxidant enzyme activities, proline contents, and growth parameters of Saccharum spp. hybrid cv. HSF-240 under salt stress. Turk. J. Biol., 36: 630-640.

Belkhadi, A., Hediji, H., Abbes, Z., Nouairi, I., Barhoumi, Z., Zarrouk, M., Chaibi, W. and Djebali, W. 2014. Effect of exogenous Salicylic acid pre treatment on $\mathrm{Cd}$ toxicity and leaf lipid content in Linumusitatissimum L. Ecotoxicity Environ., 73: 1004-1011.

Bell, L.C. and Edwards, D.G. 1987. The role of Aluminum in acidic soil Infertility Soil Management under Humid Condition. Ed. M. Lathan Bangkok., Thiland, 201-223.

Bidhan, R. and Sanjib, B. 2014. Effects of Toxic Levels of Aluminum on Seedling Parametersof Rice under Hydroponic Culture. Rice Sci., 21(4): 217-223.

Bordon, J.S. 1984. Optimization of the In vivo assay conditions for nitrate reductase in barely (Hordeumvulgare L.). J. Sci. Food Agri., 35: 725-730.

Bradford, M.M. 1976. A rapid and sensitive method for the quantitation of microgram quantity of protein utilizing the principle of protein-dye binding. Anal. Biochem., 72: 248-254. 
Cai, M., Zhang, S., Xing, C., Wang, F. and Lei, Z.N. 2011. Developmental characteristics and aluminum resistance of root border cells in rice seedlings. Plant Sci., 180: 702-708.

Cambraia, J., Pimenta, J.Á, Estevão, M.M and Sant'Anna, R.1989. Aluminum effects on nitrate uptake and reduction in sorghum. J. Plant Nutr., 12: 1435-1445.

Coombs, J., Hall, D.O., Long, S.P. and Scurlock. 1985. Techniques in bioproductivity and photosynthesis. Pergamon Press, 223-224.

Cruz, F.J.R., Lobato, A.K.K.S., Costa, R.C.L., Lope, M.J.S., Neves, H.K.B., Neto, C.F.O., Silva, M.H.L, Filho BGS, Lima Jr. A.L. and Okumura, R.S. 2011. Aluminum negative impact on nitrate reductase activity, nitrogen compounds and morphological parameters in sorghum plants. Aust. J. Crop Sci., 5: 641-645.

Dolatabadian, A., Mohammad, S.A., Sanavy, M. and Asilan, K.S. 2010. Effect of ascorbic acid foliar application on yield component and several morphological traits of grain corn under water deficit stress conditions. Notulae Scientia Biologicae, 2: 45-50.

Foy, C.D. 1996. Tolerance of barley cultivars to an acid, aluminum-toxicsubsoil related to mineral Element concentrations in their shoots. J. Plant Nutrition, 19: 1361-138.

Hamada, A.M. 2000. Amelioration of drought stress by Ascorbic Acid, thiamin and aspirin in wheat plants. Indian J. Plant Physio., 5: 358-364.

Hameda, E.S. and Ahmed, E.S. 2013. Exogenous Application of Ascorbic Acid for Improve Germination, Growth, Water Relations, Organic and Inorganic Components in Tomato (Lycopersiconesculentum Mill.) Plant under Salt-Stress. New York Sci. J., 6(10): 123-139.
Hatier, J.H.B. and Gould, K.S. 2008. Foliar anthocyanins as modulators of stress signals. J. Theoretical Biol., 253: 625627.

Hawker, J.S. and Hatch, M.D. 1965.Mechanism of sugar storage by mature stem tissue of sugarcane. Physiol. Plant, 18: 444-453.

Hawker, J.S., Walker, R.R. and Ruffner, H.P. 1976.Invertase and sucrose synthase in flowers. Phytochem., 15(10): 14411444.

Jiang, H.X., Tang, N., Zheng, J.G., Li, Y. and Chen, L.S. 2009. Phosphorus alleviates aluminum-induced inhibition of growth and photosynthesis in Citrus grandis seedlings. Physiol. Plant, 137: 298-311.

Kaiser, W.M, Weiner, H. and Huber, S.C. 1999. Nitrate reductase in higher plants: A case study for transduction of environmental stimuli into control of catalytic activity. Physiologia Plantarum, 105: 385-90.

Kochian, L.V. 1995. Cellular mechanisms of aluminum toxicity and tolerant in plants. Ann. Rev. Plant Physiol. Plant Mol. Biol., 46: 237-260.

Lee.and Takashi. 1966. An improved colorimetric determination of amino acid with the use of ninhydrin analysis. Biologia Plantarum, 14: 71-77.

Luma, C.D.S., Deise, C.S.N., Liliane, C.M., Thays, C.C., Jéssica, T.D.S.M., Cleverson, A.P.M., Najla, M.C.P., Cândido, F.D.O.N., Susana, S.C/ and Ana, E.D.A.B. 2016. Nitrogen compounds, proteins and amino acids in corn subjected to doses of aluminum. African J. Agri. Res., 11(17): 15191524.

Mahendranath, M., Santosh, C., Madan, M.M., Ramesh, L. and Radhaiah. A. 2012.Protective effect of Salicylic acid on Aluminum toxicity induced stress in Sorghum Bicolor varieties. Indian $J$. Plant Sci., 2(1). 
Malekzadeh, P.R., Sheikhakbari, M. and Hatamnia, A.A. 2015. Effects of aluminum toxicity on maize (Zea mays L.) seedlings'. Iranian J. Plant Physiol., 5(2): 1289-1296.

Mazid, M., Ali, B., Hayat, S. and Ahmad, A. 2010. The effect of 4-chloroindole-3acetic acid on some growth parameters in mung bean under cadmium stress. Turk. J. Biol., 34: 9-13.

Mona, M.A. 2008. Physiological Aspects of Aluminum Toxicity on Some Metabolic and Hormonal Contents of Hordeum Vulgare Seedlings. Australian J. Basic and Appl. Sci., 2(3): 549-560.

Muthukumaran, M. and Vijaya, B.R.A. 2014. Toxic Effects of Aluminum on Certain Protein Metabolic Parameters in Two Rice Varieties during Leaf Senescence. Res. J. Pharmaceutical Biol. Chem. Sci., 5(1): 598.

Najmeh, Z., Zahra, R. and Monireh, R. 2014. Study of aluminum toxicity on photosynthetic pigment, soluble sugars and proline content in two sunflower verities. Res. Crop Ecophysiol., 9(2): 105-113.

Palma, J.M., Sandalio, L.M., Corpas, F.J., Romero-Puertas, M.C., Mccarthy, I. and Del Rio L.A. 2002. Plant proteases, protein degradation, and oxidative stress: role of peroxisomes. Plant Physiol. Biochem., 40(6-8): 521-530.

Pal'ove-Balang, P. andMistrik, I. 2011. Effect of aluminum on nitrogen assimilation in roots of Lotus japonicus. Plant Biosyst., 145: 527-531.

Parida, A.K., Das, A.B.,Mittrac, B. and Mohanty, P. 2004. Experiment Biol Z Naturforsch C., 59(5-6): 408-14.

Pereira, L.B., Tabaldi, L.A., Goncalves, J.F., Juckeoski, G.O., Pauletto, M.M., Weis, S.N., Nicoloso, F.T., Bocher, D., Rocha, J.B.T. and Schetinger, M.R.C. 2006. Effect of aluminum on aminolevulinic acid dehydratase (ALA-D) and the development of cucumber (Cucumissativus). Environ. Exp. Bot., 57: 106-115.

Saritha, P. and Vasantha, S.P. 2016. Growth and Physiology of in Vitro Planted Seedlings of Flax (Linumusitatissimum) Under Aluminum Stress. Int. J. Sci. Res., 5(8).

Sevugaperumal, R., Selvaraj, K. and Ramasubramanian, V. 2012. Removal of Aluminum by Pandia as Bioadsorbant. Int. J. Biol. Pharmaceutical Res., 3(4): 610-615.

Sharma, P. and Dubey, R.S. 2005. Modulation of nitrate reductase activity in rice seedlings under aluminum toxicity and water stress: Role of osmolytes as enzyme protectant. $J$. Plant Physiol., 162: 854-864.

Simon, L., Kieger, M., Sung, S.S. and Smalley, T.J. 1994.Aluminum toxicity in Tomato, Part 2. Leaf Gas exchange, Chlorophyll content, and Invertase activity. J. Plant Nutri., 17(2-3): 303317.

Shuster, L. and Gifford, R.H. 1962. Assay of amylases. Arch. Biochem. Biophys., 194: 534-540.

Strid, H. 1996. Effect of root zone temperature on aluminum toxicity in two cultivar of spring wheat With different resistant to aluminum. Physiol. Plant, 97: 5-12.

Souza, L.A., Camargos, L.S. and Aguiar, L.F. 2014. Efeito do alumíniosobre compostos nitrogenadosem Urochloa spp. Rev. Biotem., 3: 33-39.

Sphear, C.R. and Souza, L.A.C. 2004.Tempo de exposição e fonte de cálcionaseleção de soja toleranteao alumínioem hidroponia. Boletim de Pesquisa e Desenvolvimento. Embrapa, 16 p.

Sun, J., Loboda, T., Sung, S.J.S. and Black, C.C. 1992. Sucrose synthase in wild tomato, Lycopersiconchmielewskii, and tomato fruit sink strength. Plant 
Physiol., 98: 1163- 1169.

Sumner, J.B. and Howell, S.F. 1935. A method for determination of saccharase activity. J. Biol. Chem., 108: 51-54.

Swain, T. and Hillis, W.E. 1959.The phenolic constituents of Prunus domestical. The quantitative analysis of phenolic constituents. J. Sci. Food Agri., 10(1): 63-68.

Umebese, C.E. and Motajo, A.F. 2008. Accumulation, tolerance and impact of aluminum, copper and zinc on growth and nitrate reductase activity of Ceratophyllum demersum (Hornwort). J. Environ. Biol., 29(2): 197-200.

Umebese, C. and Fabiyi, O.O. 2015. Ameliorative impact of Salicylic acid on growth of Ablmoschus Esculentus Var. Clemson Spineless under Aluminum toxicity. Life J. Sci., 7(2).

Varalakshmi, S., Ediga, A. and Meriga, B. 2014. Salicylic Acid Alleviates Aluminum Toxicity in Tomato Seedlings (Lycopersicum esculentum Mill.) through Activation of Antioxidant Defense System and Proline Biosynthesis. Adv. Biosci. Biotechnol.

Vetorello, V.A., Capaldi, F.R.C. and Stefanuto, V.A. 2005. Recent advance in aluminum and toxicity tolerant in higher plants. Braz. J. Plant Physiol., 17: 129-143.

Wan, Q. 2007. Effect of aluminum stress on the content of carbohydrate in Dimocarpuslongan Lour. Seedlings. Chin. J. Trop. Crops, 28(4): 10-14.

Wang, Z.Q., Xu, X.Y., Gong, Q.Q., Xie, C., Fan, W., Yang. J.L. and Zheng, S.J. 2014. Root proteome of rice studied by iTRAQ provides integrated insight into aluminum stress tolerance mechanisms in plants. J. Proteomics, 98: 189205.

Yemn, E.C. and Willis, A.J. 1954. The estimation of carbohydrates in plant extracts by anthrone. Biochem. J., 57: 508-514.

Zahra, T., Amin, B. and Shekofeh. 2015. The effect of Aluminum and Phosphorus on some of Physiology characteristics of Brassica napus. J. Stress Physiol. Biochem., 11(1): 16-28.

Zhou, X.M., Mackeuzie, A.F., Madramootoo, C.A. and Smith, D.L.J. 1999. Effects of some injected plant growth regulators, with or without sucrose, on grain production, biomass and photosynthetic activity of field-grown corn plants. Agro Crop Sci., 183: 103-110.

\section{How to cite this article:}

Shahnawaz, M.D., Rajani Chouhan and Dheera Sanadhya. 2017. Impact of Aluminum Toxicity on Physiological Aspects of Barley (Hordeum vulgare L.) Cultivars and its Alleviation through Ascorbic Acid and Salicylic Acid Seed Priming. Int.J.Curr.Microbiol.App.Sci. 6(5): 875-891. doi: https://doi.org/10.20546/ijcmas.2017.605.098 